\title{
Memahami Makna-Makna Simbolik Pada Upacara Adat Sedekah Laut Di Desa Tanjungan Kecamatan Kragan Kabupaten Rembang
}

\author{
Muhammad Abdurrohman \\ (Mohamad.abdu@gmail.com) \\ Alumni Ilmu Komunikasi FTIK USM
}

\begin{abstract}
This study aims to determine the meanings contained in the sequence of the ceremonial procession in the village of Sea Alms Tanjungan as an annual tradition organized by the local community. Theory basis used is the symbol by Susanne Langer's theory which states that a symbol or set of symbols works by connecting a concept, the general idea, pattern, or shape. Symbols are human conceptualization of a thing, there is a symbol for something. Research methods in use is descriptive qualitative, by describing the results that have been obtained from observation and depth interviews with informants. Results in the can that is symbolic ceremonies Sea Alms is a form of implementation of gratitude local community to God Almighty for the gift that has been given, as well as their respect to guard the sea are believed during this important role for the safety of the villagers Tanjungan. This research linkages with communication studies is that people can establish a value of life by applying them in the form of symbols that can be agreed upon by the perpetrators so as to form a culture.
\end{abstract}

Kata Kunci: Makna Simbolik, Sedekah Laut, Upacara Adat

\section{Pendahuluan}

Negara Indonesia merupakan negara kepulauan dan juga dikenal sebagai bangsa yang memiliki kekayaan tradisi yang banyak dan beragam. Keragaman tradisi tersebut didasarkan pada keragaman kebudayaannya yang tersebar di berbagai wilayah kepulauan Indonesia. Salah satu kekayaan budaya tersebut adalah tradisi Sedekah Laut. Sedekah Laut merupakan salah satu tradisi yang populer bagi masyarakat pesisir atau nelayan di berbagai wilayah. Sedekah laut adalah upacara selamatan dengan melarung Jolen (menghanyutkan sesaji yang di letakkan pada miniatur berbentuk kapal laut berisi buah-buahan, makanan, dan minuman). Sedekah Laut merupakan bentuk perwujudan rasa syukur para nelayan setempat kepada
Tuhan Yang Maha Pemurah. Sedekah Laut juga dimaksudkan sebagai permohonan agar para nelayan diberi keselamatan dalam mencari nafkah di laut (Achroni, 2008 : 9).

Di Jawa Tengah merupakan salah satu contoh adanya budaya Sedekah Laut yang sejak dahulu kala memang sudah ada dan sampai saat ini turun temurun dijaga dan dilaksanakan oleh sebagian besar komunitas masyarakat pesisir Jawa Tengah. Perayaan tradisi Sedekah Laut yang sudah ada sejak ratusan tahun yang lalu, tentunya hingga kini terdapat beberapa perbedaan dan kesamaan. Perbedaannya antara lain pada saat ini terdapat pengembangan kegiatan aktivitas budaya seperti pentas wayang kulit dan hiburan. Tetapi pada intinya memiliki kesamaan yaitu meminta kepada yang 
maha kuasa agar kegiatan mencari rezeki di laut pada tahun mendatang semakin mudah (Alamsyah, $2013: 2$ ).

Desa Tanjungan Kecamatan Kragan Kabupaten Rembang merupakan salah satu desa yang hingga kini masih melestarikan budaya Sedekah Laut sebagai tradisi rutin tahunan. Desa yang memiliki luas 110.3704 Ha tersebut berbatasan dengan sebelah utara yaitu Laut Jawa, sebelah selatan desa Mojokerto, sebelah barat desa Kebloran, dan sebelah timur desa Kalipang. Tradisi Sedekah Laut desa Tanjungan merupakan suatu bentuk upacara tradisional yang dilakukan oleh warga setempat dan tamu undangan yang dipimpin oleh sesepuh ataupun pemuka adat desa tersebut. Masyarakat desa Tanjungan masih mempercayai bahwa nenek moyang mereka juga mempunyai peran dengan kemakmuran serta ketentraman warga desa Tanjungan yang mayoritas memiliki mata pencaharian sebagai nelayan, dan secara geografis letak wilayah desa Tanjungan berada di pesisir laut Utara Pulau Jawa.

Perayaan pesta laut atau yang sering disebut Sedekah Laut di desa Tanjungan yang diselenggarakan setahun sekali yaitu dengan membuat sesaji berupa makanan, buah-buahan, jajanan dan dilarung seseji tersebut kedalam laut serta biasanya di iringi musik drum band dan dilakukan doa ritual bersama. Dalam upacara tersebut dipastikan mempunyai makna tersendiri bagi masyarakat setempat. Bukan hanya mengikuti tradisi yang diturunkan oleh nenek moyang dari jaman dahulu, pastinya masyarakat setempat mengerti akan makna-makna yang terkandung dalam upacara adat tersebut. Setiap runtutan acara upacara adat tersebut maupun sesaji dan pernakpernik lainnya tentunya terdapat simbol- simbol yang mempunyai arti tersendiri dalam upacara adat tersebut.

Peneliti memilih Desa Tanjungan Kecamatan Kragan Kabupaten Rembang sebagai objek penelitian karena pada pelaksanaan upacara adat Sedekah Laut di Desa Tanjungan masih memegang banyak unsur tradisional, termasuk pada hiburan yang di sajikan dalam rangkaian prosesi Sedekah Laut. Berbeda pada daerah-daerah lain yang sama-sama memiliki tradisi tersebut, akan tetapi terdapat penambahan pertunjukan seniseni modern sebagai hiburan dalam acara pesta laut tersebut.

Tradisi yang turun temurun hingga saat ini masih di laksanakan oleh masyarakat Desa Tanjungan dan menjadi budaya tahunan, telah menjadi bukti bahwa budaya terbentuk dari pola pemikiran manusia. Fransiskus Simon dalam bukunya menjelaskan, kebudayaan dalam pemahaman klasik kerap diduga berasal dari bahasa Sansekerta, yakni buddhayah. Kata tersebut terdiri dari kata "budi" dan "daya". Budi adalah makna akal, pikiran, pengertian, paham, pendapat, perasaan. Sedangkan daya mengandung kompleksitas makna dari yang tersurat dalam budi, juga sebagai himpunan kemampuan dan segala usaha yang dikerjakan dengan menggunakan hasil pendapat budi untuk memperbaiki sesuatu dengan tujuan mencapai kesempurnaan. Perkembangan pemahaman selanjutnya, yang sering digunakan dalam berbagai keperluan, adalah kebudayaan sebagai pernak-pernik hasil akal budi dan hasil karya kesenian, keseluruhan kebiasaan dan tradisi serta pola-pola perilaku dalam setiap suku (Simon, 2006 : 9). Jadi kebudayaan merupakan hasil karya, rasa dan cipta masyarakat yang menghasilkan berupa kebudayaan kebendaan yang di abadikan 
di masyarakat, dan rasa yaitu terwujud dalam bentuk kaidah dan nilai-nilai yang ditanamkan kepada masyarakat sebagai aturan di daerahnya.

Kebudayaan mempunyai hubungan yang erat dengan komunikasi. Menurut Walstrom (dalam Liliweri) komunikasi merupakan pengalihan informasi dari seseorang kepada orang lain (Liliweri 2003: 08). Dengan demikian budaya tidak akan tercipta tanpa adanya komunikasi. Melalui komunikasi masyarakat dapat mewariskan unsurunsur kebudayaan dari satu generasi ke generasi berikutnya serta dari satu tempat ke tempat lainnya. Budaya merupakan hasil perumusan pemikiran manusia yang di bentuk dan di publikasikan melalui komunikasi.

Manusia membentuk kebudayaan dengan mengkomunikasikan sesuatu hal melalui simbol-simbol. Dalam buku Deddy Mulyana, Ernst Cassirer mengatakan bahwa keunggulan manusia atas makhluk lainnya adalah keistimewaan mereka sebagai animal symbolicum. Lambang atau simbol adalah suatu yang digunakan untuk menunjuk sesuatu lainnya, berdasarkan kesepakatan sekelompok orang. Simbol meliputi kata-kata (pesan verbal), perilaku non verbal, dan objek yang maknanya disepakati bersama (Mulyana, 2010 : 92). Kemampuan manusia untuk berkomunikasi dengan menciptakan bahasa simbolik sebagai pemaknaan terhadap nilai-nilai maupun suatu hal lainnya yang akhirnya membentuk suatu kebudayaan.

Berdasarkan fenomena diatas maka peneliti tertarik untuk melakukan penelitian komunikasi tentang memahami makna-makna simbolik dalam prosesi upacara adat Sedekah Laut di desa
Tanjungan Kecamatan Kragan Kabupaten Rembang.

Pentingnya penelitian ini bagi peneliti maupun pembaca yaitu untuk memperoleh gambaran yang lebih jelas mengenai salah satu budaya yang ada di Jawa Tengah yaitu budaya Sedekah Laut. Seiring berkembangnya teknologi komunikasi tidak jarang seseorang kerap mengabaikan dan kurang memahami dengan kebudayaan tradisional yang di turunkan oleh nenek moyang kita. Dengan demikian adanya penelitian ini bertujuan mengajak pembaca untuk memahami tentang simbol-simbol yang terkandung dalam prosesi upacara adat Sedekah Laut di desa Tanjungan Kecamatan Kragan Kabupaten Rembang sebagai fenomena komunikasi yang membentuk suatu budaya.

\section{Tinjauan Pustaka}

\section{Teori Simbol (Susanne Langer)}

Dalam buku Teori Komunikasi oleh Little John menjelaskan bahwa, Susanna Langer seorang filsuf, memikirkan simbolisme yang menjadi inti pemikiran filosofi karena simbolisme mendasari pengetahuan dan pemahaman semua manusia. Simbol digunakan dengan cara yang lebih kompleks dengan membuat seseorang untuk berpikir tentang sesuatu yang terpisah dari kehadirannya. Sebuah simbol adalah "sebuah instrumen pemikiran-pemikiran". Simbol adalah konseptualisasi manusia tentang suatu hal, sebuah simbol ada untuk sesuatu (Little John, 2009 : 153).

Sebuah simbol atau kumpulan simbolsimbol bekerja dengan menghubungkan sebuah konsep, ide umum, pola, atau bentuk. Menurut Langer, konsep adalah makna yang disepakati bersama-sama antara pelaku komunikasi. Bersama, makna yang disetujuai adalah makna 
denotatif, sebaliknya, gambaran atau makna pribadi adalah makna konotatif (Little John, 2009 : 154).

Suatu tanda atau simbol merupakan suatu stimulus yang menandai kehadiran sesuatu yang lain. Dengan demikian suatu tanda berhubungan erat dengan maksud tindakan yang sebenarnya (Morissan, 2013 : 89). Makna yang kita berikan pada sebuah simbol merupakan produk dari interaksi sosial dan menggambarkan kesepakatan kita untuk menerapkan makna tertentu pada simbol tertentu. Di contohkan dengan sebuah cincin yang merupakan simbol ikatan resmi dan emosional, dan karenanya kebanyakan orang menghubungkan simbol ini dengan konotasi yang positif. Walaupun demikian, beberapa orang melihat pernikahan sebagai sebuah institusi yang opresif. Orang-orang tersebut akan memberikan reaksi yang negatif terhadap cincin kawin dan segala simbol lainnya yang mereka anggap sebagai situasi yang merendahkan (Richard West 2008 : 99).

Begitu pun pada penelitian ini yang di dalamnya terdapat makna yang di bentuk oleh proses interaksi sosial sehingga membentuk kesepakatan bersama untuk memaknai suatu simbol tersebut. Karena bisa saja pada upacaca adat Sedekah Laut memiliki arti yang berbeda pada tempat yang berbeda, karena semua bergantung pada pelaku kelompok masyarakatnya.

Sebuah simbol atau kumpulan simbolsimbol bekerja dengan menghubungkan sebuah konsep, ide umum, pola, atau bentuk. Menurut Langer, konsep adalah makna yang disepakati bersama-sama antara pelaku komunikasi. Bersama, makna yang disetujuai adalah makna denotatif, sebaliknya, gambaran atau makna pribadi adalah makna konotatif. Langer mencontohkan dengan jika kita sedang melihat sebuah lukisan karya Vincent Van Gogh, kita akan memberikan makna bersama-sama dengan orang yang sedang melihat lukisan tersebut secara nyata, dengan makna denotatif. Begitu juga dengan si pelukis sendiri mempunyai makna pribadi sendiri atau konotasi untuk arti dari lukisan tersebut.

Langer memandang makna sebagai sebuah hubungan kompleks diantara simbol, objek, dan manusia yang melibatkan denotasi (makna bersama) dan konotasi (makna pribadi). Abstraksi, sebuah proses pembentukan ide umum dari sebentuk keterangan konkret, berdasarkan pada denotasi dan konotasi dari simbol. Langer mencatat bahwa proses manusia secara utuh cenderung abstrak. Ini adalah sebuah proses yang mengesampingkan detail dalam memahami objek, peristiwa, atau situasi secara umum.

Hal tersebut menjelaskan suatu benda maupun peristiwa dengan simbol tertentu, dapat diartikan dengan luas secara pemaknaannya. Langer mencontohkan dengan kata Anjing, secara denotatif mengacu pada sebuah binatang berkaki empat, tetapi bukan gambaran secara keseluruhan, tingkatan detail apa pun atau abstraksi selalu menyisakan sesuatu. Semakin abstrak simbol, gambaran semakin kurang lengkap (Little John, 2009 : 154-155).

Keterkaitan dengan penelitian ini yaitu sama-sama mengungkap tentang simbol yang bisa diartikan secara luas maupun abstraksi. Sebagai contoh dalam konteks penelitian ini yaitu, sesaji dalam upacara adat sedekah laut di desa Tanjungan Kecamatan Kragan Kabupaten Rembang merupakan salah satu dari simbol, hal tersebut dapat diartikan secara luas, mungkin sekilas jika kita melihat 
sesaji tersebut hanyalah berupa sekumpulan makanan, jajanan, dan buahbuahan yang dapat dimakan dan sudah tidak asing lagi bagi kita karena setiap hari kita juga menjumpai makanan, buahbuahan, dan jajanan. Akan tetapi bagi masyarakat desa Tanjungan yang mempunyai adat sedekah laut itu sendiri pastinya mempunyai makna yang berbeda dan tersendiri mengenai sesaji tersebut. Mereka pastinya mempunyai anggapan yang lebih dan berbeda dengan kita yang hanya memandang sebagai hal yang biasa.

\section{Sifat Simbol}

Dalam (Mulyana, 2010 : 92) menjelaskan bahwa simbol mempunyai beberapa sifat, yaitu sebagai berikut :

1. Simbol bersifat sembarang, manasuka, atau sewenang-wenang. Apa saja bisa dijadikan lambang, bergantung pada kesepakatan bersama. Kata-kata (lisan atau tulisan), isyarat anggota tubuh, makanan, cara makan, tempat tinggal, jabatan (pekerjaan), olahraga, hobi, peristiwa, hewan, tumbuhan, gedung, alat (artefak), angka, bunyi, waktu, dan sebagainya. Semua hal tersebut bisa menjadi lambang atau simbol.

2. Simbol pada dasarnya tidak mempunyai makna, kitalah yang memberikan makna pada simbol. Makna sebenarnya ada dalam kepala kita, bukan terletak pada simbol itu sendiri. Kalaupun ada orang yang mengatakan bahwa kata-kata mempunyai makna, yang ia maksudkan sebenarnya bahwa katakata itu mendorong orang untuk memberi makna ( yang telah disetujui bersama) terhadap kata-kata itu. Sebagian orang percaya bahwa angkaangka tertentu mengandung maknamakna tertentu, misalnya: kualitas (bagus atau jelek), kekuatan, keberuntungan, atau kesialan. Begitulah angka 9 atau 10, seperti huruf A (nilai ujian mahasiswa), sering diasosiasikan dengan kualitas atau prestasi yang tinggi. Namun angka rendah pada urutan 1,2,3 justru menunjukkan kualitas tertinggi bila digunakan untuk mengukur calon anggota DPR atau DPRD.

3. Simbol atau lambang itu bervariasi Simbol itu bervariasi dari suatu budaya ke budaya lain, dari suatu tempat ke tempat lain, dan dari suatu konteks waktu ke konteks waktu lain. Begitu juga makna yang diberikan kepada lambang tersebut. Untuk menyebut benda yang biasanya di digunakan untuk membaca pada orang Indonesia menggunakan kata buku, orang Jepang hon, orang Inggris book, orang Jerman buch, orang Belanda boek, dan orang Arab kitab. Pendek kata, hanya memerlukan kesepakatan mengenai suatu lambang. Jika semuanya sepakat, kita bisa saja menyebut benda berkaki empat yang biasa kita duduki bukanlah "kursi".

\section{Pembahasan}

Dari hasil penelitian yang di dapat dari observasi dan juga wawancara mendalam dengan informan yang di tentukan, di dapatkan hasil bahwa Tradisi upacara adat Sedekah Laut yang di selenggarakan oleh masyarakat Desa Tanjungan Kecamatan Kragan Kabupaten Rembang sebagai ritual budaya tahunan, dalam prosesinya berlangsung selama dua hari dua malam dengan berbagai kegiatan yaitu pembukaan pembukaan, inti ritual Sedekah laut, hiburan, dan penutup.

Pada pembukaan ritual Sedekah laut di sambut dengan pagelaran kesenian tradisional budaya Jawa yaitu seni tayub. 
Pelaksanaan pagelaran tersebut biasanya berlangsung pada malam hari, dimana malam sebelum berlangsungnya acara inti dari prosesi Sedekah Laut yang dilakukan di pagi harinya. Seni tayub sendiri bagi masyarakat Tanjungan memiliki arti sebagai pemujaan kepada sang pencipta lewat Keindahan dan kemerduan tembang-tembang yang di alunkan. Di dalam lantunan syair tayuban tersebut sebenarnya terdapat banyak sekali kalimat persuasif yang pada intinya adalah pemujaan terhadap sang Pencipta serta mengandung unsur mengajak kepada manusia untuk terus melakukan kebaikan. Upacara Sedekah Laut biasanya di selenggarakan pada setiap bulan Selo (Syawal). Hal ini menurut narasumber bulan Syawal merupakan bulan kemenangan, bulan dimana orang meraih puncak dari tirakat (Berusaha) pada bulan Ramadhan. Hal tersebut dianggap sesuai dengan wujud rasa syukur dan menurut masyarakat Desa Tanjungan sangat tepat dilakukan upacara Sedekah Laut.

Kemudian pada inti ritual upacara Sedekah Laut yaitu dengan melarung sesaji ke tengah laut oleh masyarakat setempat. Pada upacara Sedekah laut di Desa Tanjungan ini, sesaji berisikan nasi tumpen dan kepala kambing sebagai persembahan untuk di larung.

Sesaji sendiri memiliki makna yaitu Suatu bentuk perjuangan para masyarakat Tanjungan secara ikhlas ingin shodakoh (sedekah) sebagai bukti rasa syukur dan mengharap semoga Tuhan melihat kebaikan mereka, serta berharap keberkahan atau ingin mendapatkan nilai tambah untuk mereka. Selain itu sesaji merupakan suatu bentuk pemberian masyarakat akan barang-barang yang di anggap Aji (berharga) bagi mereka, barang-barang yang mempunyai nilai lebih yang dianggap mereka pantas di persembahkan kepada sang Pencipta dan sang Dewa laut (penjaga laut yang mereka yakini).

Adapun di dalam sesaji tersebut berisi nasi tumpeng dan kepala kambing yang juga memilik makna tersendiri bagi masyarakat Desa Tanjungan. Pemilihan sesaji dengan menggunakan nasi tumpeng karena menurut pemuka adat setempat nasi tumpeng dianggap mempunyai keutamaan yang mengandung berkah. Oleh karena itu masyarakat Desa Tanjungan beranggapan bahwa dengan menyediakan nasi tumpeng sebagai sesaji pada ritual Sedekah Laut, mereka berharap agar acara yang diselenggarakan akan memberikan kebaikan bagi masyarakat Desa Tanjungan. Nasi tumpeng bagi mereka memiliki makna suatu bentuk simbol masyarakat Desa Tanjungan ingin menempatkan sang pencipta pada posisi puncak atau posisi paling tertinggi yang menguasai alam dan manusia. Bentuk mengerucut yang di ibaratkan sebagai sang Pencipta menduduki posisi paling tinggi di maksudkan sebagai wujud hormat dan rasa syukur terhadap segala sesuatu yang telah diberikan oleh Tuhan Yang Maha Esa.

Selain itu, kepala kambing yang merupakan salah satu bagian dari sesaji upacara Sedekah Laut memiliki filosofi tersendiri, bahwa kepala kambing mempunyai simbol kekayaan masyarakat Tanjungan yang telah di hasilkan dari laut, kambing di ibaratkan sesuatu yang berharga di masa dulu yang sudah didapat dari laut. Untuk itu sebagai wujud terimakasih para masyarakat memberikan persembahan kepala kambing yang nantinya di larung ke dalam laut. Acara pelarungan sesaji yang di lakukan masyarakat merupakan inti dari runtutuan upacara adat Sedekah Laut di Desa 
Tanjungan. Setelah pelarungan selesai dilaksanakan, puncak acara Sedekah Laut di anggap sudah selesai, dan dilanjutkan dengan acara hiburan yang di pertunjukkan kepada masyarakat.

Pada malam hari seusai hari dimana ritual pelarungan sesaji atau acara inti dilakukan, masyarakat Desa Tanjungan disuguhkan dengan kesenian budaya yang kedua kalinya, yaitu berupa ketoprak (wayang orang). tujuan diadakannya pertunjukan wayang orang yaitu selain untuk memperkukuh kebersamaan masyarakat Desa Tanjungan, mereka juga ingin melestarikan kebudayaan tradisional yang saat ini sudah mulai hilang perlahan-lahan. Di sisi lain Pemilihan seni ketoprak sebagai hiburan pada saat acara Sedekah Laut karena Menurutnya kesenian tradisional ketoprak merupakan kesenian yang menampilkan cerita-cerita dengan bertujuan mendidik serta memberi pesan yang positif kepada masyarakat sekaligus juga memberikan hiburan. Informan juga menambahkan cerita jika pada dahulu kala di desa Tanjungan pada saat prosesi Sedekah Laut pernah tidak menampilkan kesenian tradisional ketoprak, dan pada saat itu juga terjadi angin kencang melanda desa mereka, cerita tersebut berdasarkan orang-orang pendahulu mereka sehingga akhirnya sekarang mereka masih banyak yang mempercayai bahwa pada prosesi upacara Sedekah Laut perlu mendatangkan kesenian tradisional ketoprak (wayang orang).

Setelah dilakukan pertunjukan kesenian wayang orang pada malam hari setelah dilakukannya acara inti Sedekah Laut, pada keesokan harinya yang merupakan hari terakhir pada runtutan prosesi Sedekah Laut, di tutup dengan pengajian bersama atau doa bersamasama masyarakat Desa Tanjungan. Acara ini dilakukan karena memang mayoritas penduduk desa Tanjungan beragama muslim. Tetapi mereka tidak membedabedakan dengan orang selain muslim di desa tersebut. Mereka semua tetap ikut membaur sebagai satu kesatuan masyarakat Tanjungan yang saling berterimakasih atas keberkahan yang telah diberikan kepada mereka, serta wujud permohonan doa untuk di tahun kedepan semakin di tambah kenikmatan dan di hindarkan dari suatu musibah ketika mereka mencari nafkah di laut. Dengan tidak membeda-bedakan keragaman agama tersebut merupakan hal penting sebagai kelestarian tradisi upacara Sedekah Laut di desa Tanjungan.

\section{Kesimpulan}

Dari ulasan tentang makna-makna simbolik yang terkandung dalam bagianbagian prosesi upacara adat Sedekah Laut di Desa Tanjungan Kecamatan Kragan Kabupaten Rembang terdapat kesimpulan bahwa, upacara adat Sedekah Laut di desa Tanjungan merupakan suatu tradisi yang di bentuk oleh masyarakat setempat dengan mengaplikasikan suatu nilai-nilai kebaikan pada setiap runtutan prosesinya. Suatu nilai yang di dalamnya mengungkapkan tentang rasa syukur masyarakat desa Tanjungan kepada sang pencipta atas kenikmatan yang sudah diberikan. Selain itu upacara adat Sedekah Laut di desa Tanjungan juga suatu bentuk penghormatan kepada penjaga laut atau dewa dewi laut yang di yakini oleh masyarakat setempat. Dengan ungkapan rasa syukur dan rasa hormat tersebut, di bentuk suatu simbol dengan adanya upacara adat Sedekah Laut.

Simbol atau makna yang terdapat dalam setiap runtutan prosesi Sedekah Laut merupakan hasil pemikiran bersama dan kesepakatan bersama oleh 
masyarakat untuk membuat nilai-nilai yang di kemas dalam sebuah simbol sehingga membentuk kebudayaan yang di lestarikan hingga saat ini. Seperti yang di jelaskan pada teori simbol oleh Susanne Langer bahwa Simbol adalah konseptualisasi manusia tentang suatu hal, sebuah simbol ada untuk sesuatu (Littlejohn, 2009 : 153).

\section{Daftar Pustaka}

Alo Liliweri. 2003. Dasar-Dasar Komunikasi Antarbudaya. Yogyakarta: Pustaka Pelajar.

Dawud Achroni. 2008. Upacara Adat Nusantara. Surakarta: CV Suara Media Sejahtera.

Deddy Mulyana. 2010. Ilmu Komunikasi (Suatu Pengantar). Bandung: PT Remaja Rosdakarya.

Fransiskus Simon. 2006. Kebudayaan Dan Waktu Senggang. Jogjakarta : Jalasutra.

Little John, Stephen W \& Karen A. Foss. 2009. Teori Komunikasi (Theories Of Human Communication) edisi 9. Jakarta : Salemba Humanika.

Lynn H. Turner, Richard West. 2008. Pengantar Teori Komunikasi Analisis Dan Aplikasi. Jakarta : Salemba Humanika.

Morissan. 2013. Teori Komunikasi. Bogor: Ghalia Indonesia.

\section{Sumber Internet}

Budaya Syawalan Atau Lomban Di Jepara dalam (http://ejournal.undip.ac.id/index.ph p/humanika/article/download/5940/
5092 . diunduh pada 24 September 2014 pukul 14.22 WIB). 